\title{
Influence of carbon anode properties on performance and microbiome of Microbial Electrolysis Cells operated on urine
}

\author{
Sónia G. Barbosa a , Luciana Peixoto a, Olívia S.G.P. Soares ${ }^{\mathrm{b}}$, Manuel Fernando R. Pereira ${ }^{\mathrm{b}}$, \\ Annemiek Ter Heijne ${ }^{c}$, Philipp Kuntke ${ }^{d}$, Maria Madalena Alves a , Maria Alcina Pereira a, * \\ ${ }^{a}$ CEB - Centre of Biological Engineering, University of Minho, Campus de Gualtar, 4710-057, Braga, Portugal \\ ${ }^{\mathrm{b}}$ Laboratory of Separation and Reaction Engineering - Laboratory of Catalysis and Materials (LSRE-LCM), Department of Chemical Engineering, Faculty of \\ Engineering, University of Porto, Rua Dr. Roberto Frias, 4200-465, Porto, Portugal \\ ${ }^{c}$ Sub-department of Environmental Technology, Wageningen University, P.O. Box 17, 6700 AA Wageningen, The Netherlands \\ ${ }^{\mathrm{d}}$ Wetsus, European Centre of Excellence for Sustainable Water Technology, Oostergoweg 9, 8911 MA Leeuwarden, The Netherlands
}

\section{A R T I C L E I N F O}

Article history:

Received 13 September 2017

Received in revised form

22 November 2017

Accepted 15 February 2018

Available online 15 February 2018

\section{Keywords:}

Microbial electrolysis cell

Microbial community

Phenolic-based carbon

Cellulose-based carbon

Polyacrilonitrile-based carbon

\begin{abstract}
A B S T R A C T
Anode performance of Microbial Electrolysis Cells (MECs) fed with urine using different anodes, Keynol (phenolic-based), C-Tex (cellulose-based) and PAN (polyacrylonitrile-based) was compared under cell potential control (1st assay) and anode potential control (2nd assay). In both assays, C-Tex MEC outperformed MECs using Keynol and PAN. C-Tex MEC under anode potential control $(-0.300 \mathrm{~V}$ vs. $\mathrm{Ag} / \mathrm{AgCl})$ generated the highest current density $\left(904 \mathrm{~mA} \mathrm{~m}^{-2}\right)$, which was almost 3-fold higher than the Keynol MEC and 8-fold higher than the PAN MEC. Analysis of anodes textural, chemical and electrochemical characteristics suggest that the higher external surface area of C-Tex enabled higher current density generation compared to Keynol and PAN. Anodes properties did not influence significantly the microbial diversity of the developed biofilm. Nonetheless, C-Tex had higher relative abundance of bacteria belonging to Lactobacillales and Enterobacteriales suggesting its correlation with the higher current generation.
\end{abstract}

๑ 2018 Elsevier Ltd. All rights reserved.

\section{Introduction}

Microbial electrolysis cells (MECs) are a specific type of Bioelectrochemical Systems (BESs), which combines the biological oxidation of organic substrate at the anode with hydrogen gas $\left(\mathrm{H}_{2}\right)$ production at the cathode [1]. Several studies have shown that $\mathrm{H}_{2}$ production can be successfully coupled to wastewater treatment in MECs [2-4]. Recently, urine was proposed as a good wastewater feed-stock for bioelectrochemical systems [5]. Urine is a liquid waste that accounts for $1 \%$ of the total volume of domestic wastewater produced. Approximately $75 \%$ of the nitrogen $(\mathrm{N})$ and $50 \%$ of the phosphorus $(\mathrm{P})$ loads found in domestic wastewater originate from urine [6]. Furthermore, urine contains a wide range of organic compounds, such as acetate that can be biologically oxidized. MECs efficiently convert chemical energy stored in organic substrate into $\mathrm{H}_{2}$, and are therefore a promising technology for renewable and sustainable $\mathrm{H}_{2}$ production. Kuntke and co-workers investigated the

\footnotetext{
* Corresponding author.

E-mail address: alcina@deb.uminho.pt (M.A. Pereira).
}

use of MEC for $\mathrm{H}_{2}$ production from diluted urine [7]. The authors demonstrated that MEC can be a promising technology for $\mathrm{H}_{2}$ production with simultaneous ammonium $\left(\mathrm{NH}_{4}^{+}\right)$and chemical oxygen demand (COD) removal from diluted urine. Nonetheless, further research is necessary to improve the conversion of the chemical energy to electrical energy [7]. Thus, an efficient electron transfer mechanism between bacteria and the anode surface is essential.

The development of the biofilm and electron transfer are strongly dependent on the anode characteristics, namely surface charge, surface wettability (hydrophobicity/hydrophilicity), surface area and conductivity [8]. Several anode materials have been used in MECs such as graphite brush [9], plain carbon cloth [10] and graphite granules [11]. As a general trend, it has been reported that increasing the surface area available for bacteria attachment to the anode materials improves the current output [12-14]. Further, Guo and co-workers showed that positively charged and hydrophilic surfaces improved electroactive biofilm growth and development [15]. To improve the performance of the MECs, a better understanding on how electrode properties affect biofilm performance is, 
therefore, necessary.

The aim of this study was to evaluate the performance of electrochemically active biofilms fed with urine on three different carbon anode materials. The anodes produced from different sources, phenol-based (Keynol), cellulose-based (C-Tex) and polyacrilonitrile (PAN) were investigated for textural, chemical and electrochemistry characterization. MEC performance was assessed by current density, coulombic efficiency (CE) and COD removal efficiency. The microbial community developed was investigated by high throughput sequencing and the relationship between the identified microorganisms and the generated current was analysed.

\section{Materials and methods}

\subsection{Urine and inoculum source}

MECs were fed with urine collected from 5 male and 5 female individuals. Urine was pre-treated by adding a magnesium source in order to remove phosphorus $(\mathrm{P})$ as a precipitate, namely struvite according to Barbosa et al. [16]. Urine composition after pretreatment is shown in Table 1. The MECs were inoculated with an anaerobic community previously enriched in "urine-degrading" electroactive microorganisms in a MFC.

In this study three types of carbon electrodes, C-Tex, Keynol and PAN (MAST Carbon International Limited, United Kingdom) were tested as anode material in MECs. Textural and electrochemical characterizations were performed before their application in the MECs.

\subsubsection{Chemical and textural characterization}

A scanning electron microscope (SEM) (Nova NanoSEM 200, FEI, USA) integrated with an energy dispersive spectrometer (EDS) (Pegasus X4M, EDAX, USA) was used to investigate the surface morphology of the different electrode materials. Elemental analysis was carried out on a vario MICRO cube analyser from Elemental GmbH (Germany) in CHNS mode. Each element (carbon (C), hydrogen $(\mathrm{H})$, nitrogen $(\mathrm{N})$ and sulphur $(\mathrm{S})$ ) was determined by combustion of the sample at $1050^{\circ} \mathrm{C}$ and calculated by the mean of three independent measurements, using a calibration with a standard compound. Also, the elemental content of oxygen $(\mathrm{O})$ on the different electrodes was carried out on a rapid OXY cube analyser from Elemental GmbH (Germany). The content of $\mathrm{O}$ was determined by pyrolysis of the sample at $1450^{\circ} \mathrm{C}$ and calculated by the mean of three independent measurements, using calibration with a standard compound.

The surface chemistry was characterized by temperature programmed desorption (TPD). The carbon monoxide (CO) and carbon dioxide $\left(\mathrm{CO}_{2}\right)$ profiles were obtained with a fully automated AMI 300 Catalyst characterization apparatus (Altamira Instruments, USA) connected to a Dycor Dymaxion Mass Spectrometer. Each sample $(0.100 \mathrm{~g})$ was heated up to $1100^{\circ} \mathrm{C}$ at $5^{\circ} \mathrm{C} \mathrm{min}^{-1}$ using a constant flow rate of helium equal to $25 \mathrm{~cm}^{3} \mathrm{~min}^{-1}$.

The textural characterization of the samples was based on the nitrogen $\left(\mathrm{N}_{2}\right)$ adsorption isotherms, determined at $-196^{\circ} \mathrm{C}$ with a Quantachrome NOVA 4200e instrument (Quantachrome, USA). The

Table 1

Composition of urine after phosphorus precipitation.

\begin{tabular}{lll}
\hline & Unit & Urine \\
\hline $\mathrm{pH}$ & & $9.04 \pm 0.03$ \\
$\mathrm{COD}$ & $\mathrm{g} \mathrm{L}^{-1}$ & $7.55 \pm 2.00$ \\
$\mathrm{TKN}$ & $\mathrm{g} \mathrm{L}^{-1}$ & $5.6 \pm 2.2$ \\
$\mathrm{NH}_{4}^{+}-\mathrm{N}$ & $\mathrm{g} \mathrm{L}^{-1}$ & $1.92 \pm 0.07$ \\
$\mathrm{PO}_{4}^{3-}-\mathrm{P}$ & $\mathrm{g} \mathrm{L}^{-1}$ & $0.05 \pm 0.01$ \\
\hline
\end{tabular}

samples $(0.100 \mathrm{~g})$ were outgassed at $150{ }^{\circ} \mathrm{C}$ for $3 \mathrm{~h}$ under vacuum. The specific surface area $\left(S_{\mathrm{BET}}\right)$ of the samples was calculated by the Brunauer-Emmett-Teller (BET) equation. The external surface area $\left(\mathrm{S}_{\text {ext }}\right)$ and the volume of micropores $\left(\mathrm{V}_{\text {micro }}\right)$ were calculated by the t-method using the standard isotherms proposed by RodriguezReinoso et al. [17]. The total specific pore volume $\left(\mathrm{V}_{\mathrm{p}}\right)$ was determined from the amount adsorbed at $\mathrm{P} / \mathrm{P}_{0}=0.95$.

The wettability (hydrophobicity/hydrophilicity) of the dry electrodes was determined through their contact angle at room temperature. Sessile drop technique was performed in an OCA20 (DataPhysics, Germany) instrument by depositing ultrapure water drops $(3 \mu \mathrm{L})$ on the sample surface and the contact angle was analysed with the SCA20 software. At least three different spots of each material were measured to provide an average contact angle measurement. The thermal stability of the electrodes were investigated by thermogravimetric analysis (TGA) using a thermogravimetric analyser (TGA 4000, PerkinElmer, USA) starting from room temperature to $800^{\circ} \mathrm{C}$ with a heating rate of $10^{\circ} \mathrm{C} \mathrm{min}^{-1}$ under a $\mathrm{N}_{2}$ flux $\left(3 \mathrm{~mL} \mathrm{~min}^{-1}\right)$. The surface functional groups of different materials were analysed by Fourier transform infrared (FTIR) spectroscopy (Spotlight 300, PerkinElmer, USA) at room temperature in the range of $400 \mathrm{~cm}^{-1}$ to $4000 \mathrm{~cm}^{-1}$.

\subsubsection{Bacterial attachment capacity}

The biomass attachment was quantitatively measured by assessed dry weight measurements. Mixed urine collected from 5 female and 5 male individuals was used as the inoculum. Small pieces of the electrodes (Keynol: $140 \pm 41 \mathrm{mg}$; C-Tex: $117 \pm 35 \mathrm{mg}$ and PAN: $90 \pm 31 \mathrm{mg}$ ) were immersed in urine for 2 weeks (room temperature and $45 \mathrm{rpm}$ ). After this period, the electrodes were dried in a drying oven at $105^{\circ} \mathrm{C}$ until a stable weight. For each electrode material, the assays were performed in triplicate. The final weight of electrodes were measured to determine the extents of bacterial attachment, biofilm formation and other aggregates [18]. The amount of attached biomass was calculated based on the difference of the weight before and after the biofilm development per amount of electrode used.

\subsubsection{Electrochemical characterization}

The electrochemical performance of the different materials was studied in a three-electrode test cell using a potentiostat (VSP, Biologic, France). Platinum foil $(2 \mathrm{~cm} \times 2 \mathrm{~cm})$ was used as the counter electrode and an $\mathrm{Ag} / \mathrm{AgCl}$ electrode was used as the reference electrode. The electrochemical measurements were carried out in $50 \mathrm{~mL}$ of $\mathrm{KOH} 1 \mathrm{M}$ at room temperature.

Cyclic voltammetry (CV) measurements were carried out between -0.9 and $0.4 \mathrm{~V}$ at different scan rates $(1,5,10,30$, and $\left.50 \mathrm{mV} \mathrm{s}^{-1}\right)$. The galvanostatic charge/discharge tests were performed at the same potential range used for $\mathrm{CV}$ at a current of $1 \mathrm{~mA}$. The specific capacitance of the various electrodes was determined from the charge-discharge curves using Equation (1), where $C$ is the capacitance per unit of the electrode surface $\left(4 \mathrm{~cm}^{2}\right)\left(\mathrm{mF} \mathrm{cm}{ }^{-2}\right)$, i is the current density $\left(\mathrm{mA} \mathrm{cm}^{-2}\right), \Delta \mathrm{t}$ is the time of discharge $(\mathrm{s}), \Delta \mathrm{V}$ is the potential window $(\mathrm{V})$ and $\mathrm{m}$ is the mass of electrode [19].

$C=i \Delta t / \Delta V m$

\subsection{Reactor set up}

An experimental set-up with three simultaneously running MECs was assembled to study the influence of the three different anode materials (Keynol, C-Tex and PAN) (surface area of $25 \mathrm{~cm}^{2}$ ) on anode performance and the developed microbial community. 
The set-up consisted of three identical dual-chambers plexiglass MECs operated at room temperature $\left(20 \pm 3^{\circ} \mathrm{C}\right)$. The different anode materials connected to a graphite insert (MAST Carbon International Limited, United Kingdom) were used as anode and NiMo (MAST Carbon International Limited, United Kingdom) connected to a graphite insert as a cathode. The graphite inserts were designed to fit in the anode compartments and contained parallel flow channels to direct the flow. At the same time, they ensured good contact between electrode material and current collector. Flat graphite plates connected to each graphite insert (Müller \& Rössner GmbH \& Co., Germany) were used as current collectors. A cation exchange membrane CMH-PP (Ralex, Mega, Czech Republic) was placed directly between the two-chambers. Urine after phosphorus removal was fed as anolyte whereas $\mathrm{NaCl}(0.1 \mathrm{M})$ was supplied as catholyte.

In the first assay, the MECs were operated in batch mode (anode volume of $300 \mathrm{~mL}$ ), under cell potential control by setting the cell potential with a potentiostat. The applied cell potential was step wise increased (100 mV), during almost 6 weeks (38 days), from $0.4 \mathrm{~V}$ to $0.9 \mathrm{~V}$. In the second assay, new electrodes were used and the MECs were operated in continuous mode (at two different hydraulic retention times (HRTs), 17 and $26 \mathrm{~min}$ ) under anode potential control. Anode potential was controlled at $-0.300 \mathrm{~V}$ vs. $\mathrm{Ag} / \mathrm{AgCl}$ using a potentiostat that according to the previous results was the anode potential that allows to obtain the highest current density. The electrochemical instrumentation consisted of a potentiostat (VSP, Biologic, France) used to control potential and a data acquisition software (EC-Lab software) to record data such as current density. All anode voltages are reported vs. $\mathrm{Ag} / \mathrm{AgCl}$ $(+0.210 \mathrm{~V}$ vs. NHE $)$

\subsection{Chemical analysis and measurements}

During the experiments, samples were taken from the anode effluent compartment and were analysed for SCOD concentration using Hach-Lange cuvette tests (Hach Lange, Düsseldorf, Germany) and a spectrophotometer DR 2800 (Hach Lange, Düsseldorf, Germany). All samples were previously centrifuged at 10000 rotations $\mathrm{min}^{-1}$ for $5 \mathrm{~min} \mathrm{pH}$ was also measured using a portable $\mathrm{pH}$ meter (HI 83141, Hanna, Italy).

Current density was determined dividing the current obtained by the area of each anode $\left(25 \mathrm{~cm}^{2}\right)$. CE which was determined from the measured current and the removed COD as described by Logan and co-workers [1]. CV was used to characterize electron transfer mechanism at the surface of the different anodes. The current density in response to the anode potential, in a range from $-0.900 \mathrm{~V}$ to $0.800 \mathrm{~V}$, was recorded directly from the potentiostat output at a scan rate of $0.15 \mathrm{mV} \mathrm{s}^{-1}$.

\subsection{Microbial community investigation}

The biofilm attached at each anode was collected by cutting small pieces of electrode. In addition, the initial inoculum was also investigated for comparison of the microbial community. The samples were preserved at $-20^{\circ} \mathrm{C}$ until analysis. DNA from the different biofilms was extracted using the FastDNA spin kit for soil (MP Biomedicals, USA) according to the manufacturer's guidelines. The concentration of the extracted DNA was measured using a nanodrop equipment (Thermo Scientific, USA). The DNA samples were sent for high throughput sequencing using an Illumina MiSeq platform (Research and Testing Laboratory-RTL, USA). The MiSeq method used was the Illumina two-step [20]. Specific primer sets for the amplification of bacterial (Bakt_341F/Bakt_805R) [21] and archaeal (Arch349F/Arch806R) [22] domains were used. Illumina sequencing data was submitted to the European Nucleotide
Archive, under the study accession number PRJEB20142, and can be viewed by following the URL: http://www.ebi.ac.uk/ena/data/view/ PRJEB20142.

\section{Results and discussion}

\subsection{Electrodes characterization}

\subsubsection{Chemical and textural characterization}

Fig. 1 shows images of the carbon fibers of the different carbon electrodes at 160x and 1000x magnification obtained by SEM. The SEM images show that all three electrodes present uniform morphology over the whole sample. The fibers cross sections represent a circular shape with an average diameter of $6.5 \pm 1.2 \mu \mathrm{m}$ for Keynol, $7.3 \pm 1.2 \mu \mathrm{m}$ for C-TEX and $6.9 \pm 0.8 \mu \mathrm{m}$ for PAN. The elemental analysis showed that Keynol is composed of 78.9\% C, 9.1\% $\mathrm{O}$ and $2.0 \% \mathrm{H}$. C-Tex is composed of $74.6 \% \mathrm{C}, 11.1 \% \mathrm{O}, 1.2 \% \mathrm{H}$ and $1.15 \%$ N. PAN is composed of $88.2 \% \mathrm{C}, 1.2 \% \mathrm{O}, 0.6 \% \mathrm{H}$ and $7.1 \% \mathrm{~N}$. The sum of $\mathrm{CNOH}$ for each anode material was not $100 \%$, suggesting that other compounds mainly inorganics can be present in the sample.

Fig. 2 shows the TPD profiles of the different electrodes in study. An increase of the $\mathrm{CO}$ and $\mathrm{CO}_{2}$ peaks corresponds to an increase in the amount of functional groups containing oxygen. The TPD peaks were assigned to the different oxygen functional groups by comparison with the data exhibited $[23,24]$. According to Chen and coworkers, oxygen-containing groups on the carbon surface improve the surface hydrophilicity and the contact between the electrode surface and electrolyte [25]. The polarity of the oxygen functional groups promotes the reaction between the oxygen, at the carbon surface, and water molecules in the electrolyte by hydrogen bonds, increasing the hydrophilicity of the electrode surface [26]. The TDP profile of C-Tex showed larger $\mathrm{CO}$ and $\mathrm{CO}_{2}$ peaks, which corresponds to higher amount of oxygen functional groups, compared with the other materials (Keynol and PAN), suggesting that the cell adhesion is promoted on the C-Tex surface.

The results of textural characterization obtained from the $\mathrm{N}_{2}$ equilibrium adsorption isotherms are presented in Table 2. The shape of Keynol and C-Tex $\mathrm{N}_{2}$ sorption isotherms (Fig. A) is of type I according to IUPAC, demonstrating that the pores present in these electrodes are essentially micropores $(\mathrm{d}<2 \mathrm{~nm})$ [27]. Table 2 shows that on Keynol $90 \%$ of the total pore volume are micropores, whereas on C-Tex the micropores volume corresponds to $55 \%$. The shape of the PAN $\mathrm{N}_{2}$ sorption isotherm is of type II, which is typical for multi-layer adsorption in non-microporous materials (Fig. A). Table 2 shows that the volume of pores on PAN is insignificant compared with the other electrodes. According to these results, Keynol showed a slightly higher $\mathrm{S}_{\mathrm{BET}}\left(1234 \mathrm{~m}^{2} \mathrm{~g}^{-1}\right)$ compared to CTex $\left(1090 \mathrm{~m}^{2} \mathrm{~g}^{-1}\right)$ and a largely higher $\mathrm{S}_{\mathrm{BET}}$ compared to PAN $\left(13 \mathrm{~m}^{2} \mathrm{~g}^{-1}\right)$. The high $\mathrm{S}_{\mathrm{BET}}$ of Keynol and C-Tex can be attributed to their large amount of micropores. However, given the size of a typical bacteria $(1-3 \mu \mathrm{m})$, high $\mathrm{S}_{\mathrm{BET}}$ does not necessarily increase the surface area available for bacterial attachment [28]. According to Lu and co-workers, only pores with a large diameter, such as macropores $(\mathrm{d}>50 \mathrm{~nm})$ and pores introduced by material assembly contribute to the surface area available for biofilm formation [29]. The $S_{\text {ext }}$ was also determined, which corresponds to the surface area of the materials excluding the contribution of micropores. C-Tex present the highest $\mathrm{S}_{\text {ext }}\left(305 \mathrm{~m}^{2} \mathrm{~g}^{-1}\right)$ compared to the other electrodes ( $70 \mathrm{~m}^{2} \mathrm{~g}^{-1}$ for Keynol and $13 \mathrm{~m}^{2} \mathrm{~g}^{-1}$ for PAN).

Biofilm attachment to the different electrodes was determined quantitatively by measuring the "dry mass" of the materials before and after biofilm development. The amount of microorganisms attached was normalized to the anode weight. The results showed that biofilm amount per weight of electrode was higher in the C-Tex $\left(648 \pm 210 \mathrm{mg} \mathrm{g}^{-1}\right)$ compared with Keynol $\left(334 \pm 96 \mathrm{mg} \mathrm{g}^{-1}\right)$ and 

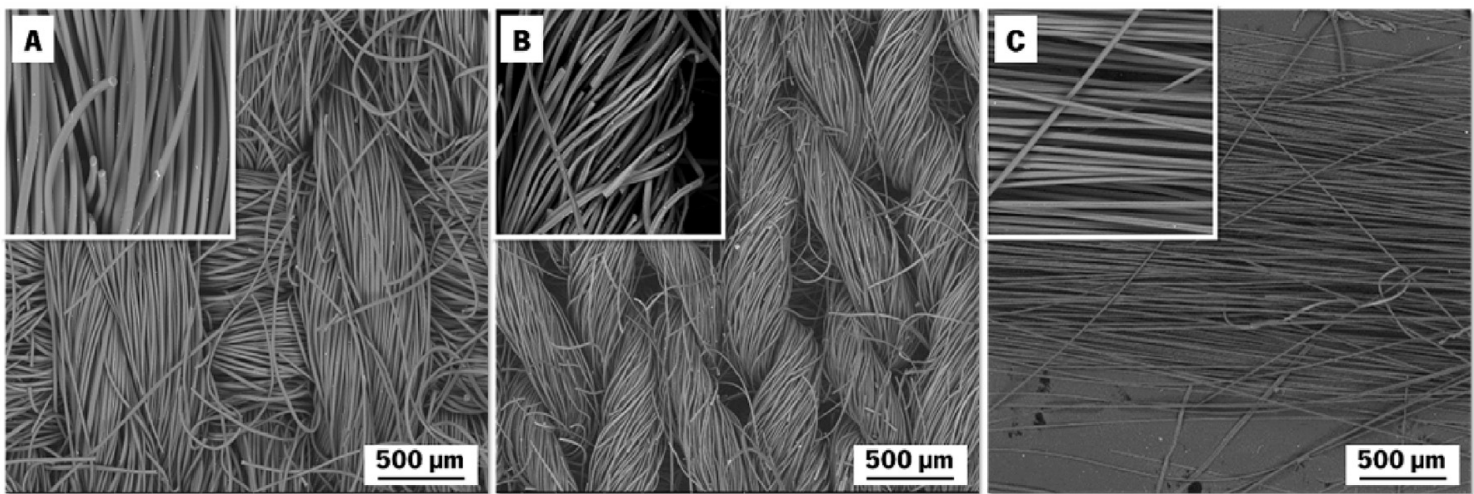

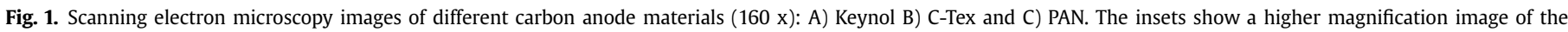
electrodes $(1000 \mathrm{x})$.
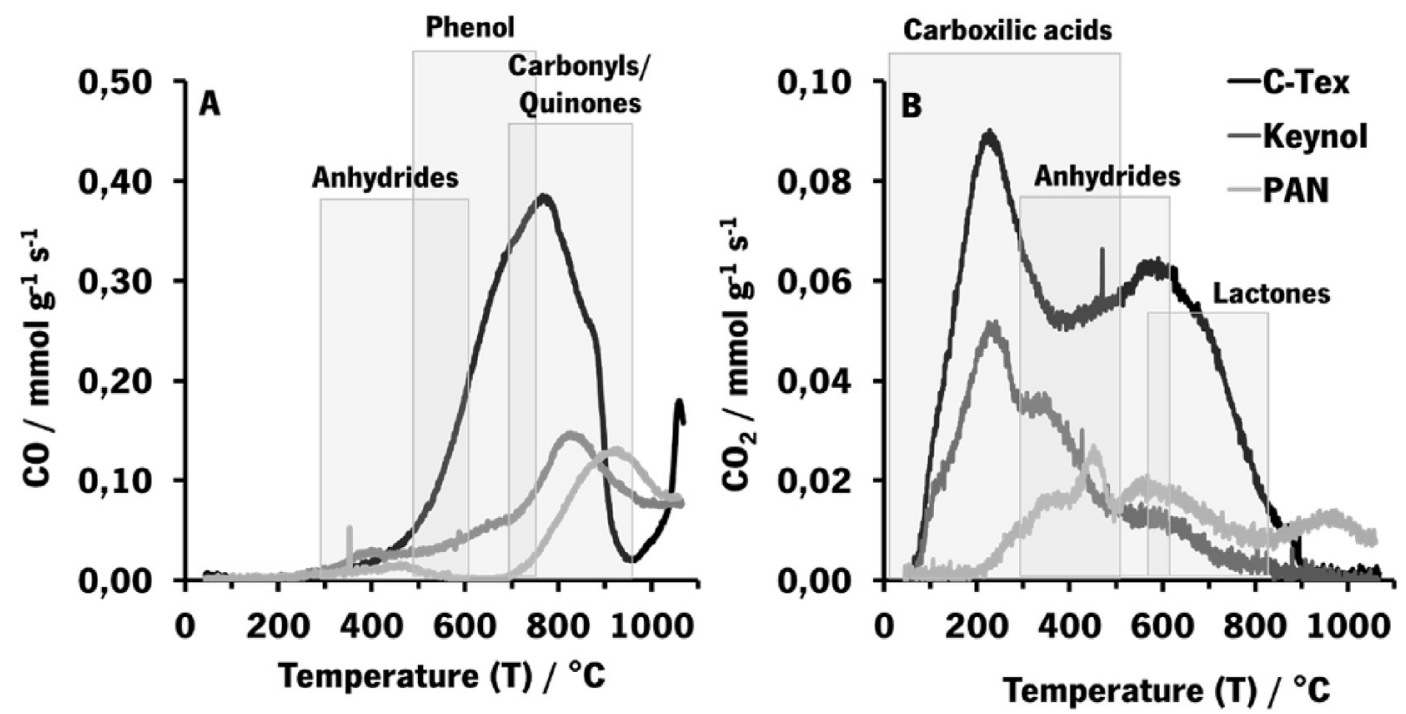

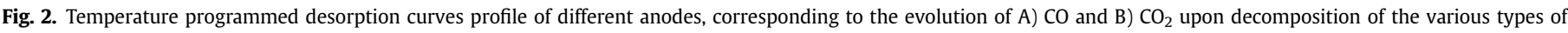
oxygen functional groups.

Table 2

Textural characterization of the different anode materials.

\begin{tabular}{lllll}
\hline Anode material & $S_{\mathrm{BET}} \mathrm{m}^{2} \mathrm{~g}^{-1}$ & $S_{\text {ext }} \mathrm{m}^{2} \mathrm{~g}^{-1}$ & $V_{\text {micro }} \mathrm{cm}^{3} \mathrm{~g}^{-1}$ & $V_{\mathrm{P}}^{\mathrm{a}} \mathrm{cm}^{3} \mathrm{~g}^{-1}$ \\
\hline C-Tex & 1090 & 305 & 0.319 & 0.574 \\
PAN & 13 & 13 & 0.000 & 0.012 \\
Keynol & 1234 & 70 & 0.553 & 0.610 \\
\hline
\end{tabular}

${ }^{\mathrm{a}} \mathrm{P} / \mathrm{Po}=0.95$.

comparable to PAN $\left(518 \pm 57 \mathrm{mg} \mathrm{g}^{-1}\right)$. Since the external surface area of PAN ( $13 \mathrm{~m}^{2} \mathrm{~g}^{-1}$ ) was significantly lower than the external surface area of C-Tex $\left(305 \mathrm{~m}^{2} \mathrm{~g}^{-1}\right)$, this suggest that the biofilm developed at the PAN was thicker. According to Ishii and coworkers thin biofilms are more electrogenic since promote the electron transfer directly to the electrode surface, the accessibility to the substrate and the diffusion of protons [30]. A positive relationship between the $S_{\text {ext }}$ of the C-Tex and the amount of biofilm attachment was found, suggesting that C-Tex presented a higher surface area available for biofilm development. Possibly the high amount of micropores ( $90 \%$ of the total pore volume) on Keynol was responsible for the lower biofilm attachment.

The wettability of the electrode surfaces also influences the biofilm development and can lead to significant differences in
MECs performance. Water contact angles between $60^{\circ}$ and $80^{\circ}$ have been described as an adequate level of surface wettability for optimal biofilm formation [31]. The hydrophilic property of the electrodes surface was determined by measuring the contact angle between the water droplet and the electrode surface. If the contact angle is higher than $90^{\circ}$, the surface can be considered hydrophobic. If the contact angle is less than $90^{\circ}$, the surface can be considered hydrophilic [32]. At time zero, C-Tex and Keynol demonstrated a contact angle equal to $0^{\circ}$ indicating that these materials can be considered hydrophilic, while PAN demonstrated a contact angle of $124 \pm 6^{\circ}$ indicating its hydrophobic behaviour. Although, nitrile groups are polar, polyacrylonitrile polymer structures are insoluble in water. The presence of nitrile group at the PAN surface was confirmed by the $\mathrm{C} \equiv \mathrm{N}$ band $\left(2260 \mathrm{~cm}^{-1}\right.$ to $2210 \mathrm{~cm}^{-1}$ ) detected in the FTIR analysis (Table A). The hydrophilic properties of C-Tex are possible due to the large amount of oxygen functional groups identified on their surface (Fig. 2). According to Guo and co-workers, hydrophilic surfaces improve the electroactive biofilm formation [15].

The thermal stability of the electrode materials was evaluated by TGA. Fig. 3 shows the thermogravimetric (TG) and derivative thermogravimetric (DTG) curves for electrodes under $\mathrm{N}_{2}$ atmosphere from room temperature to $800^{\circ} \mathrm{C}$. According to the results, 

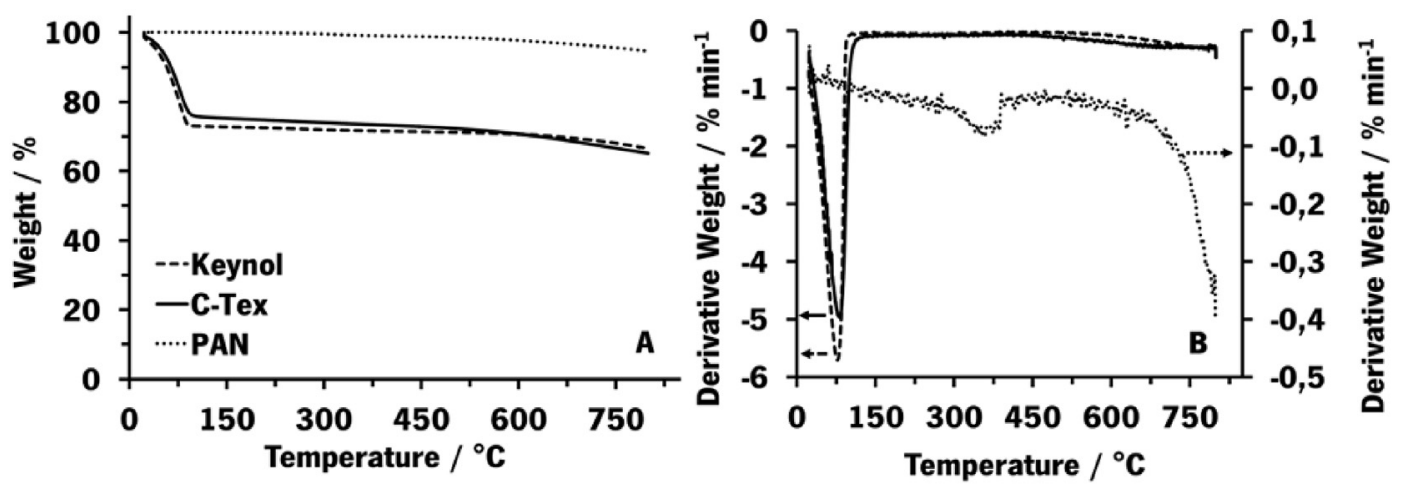

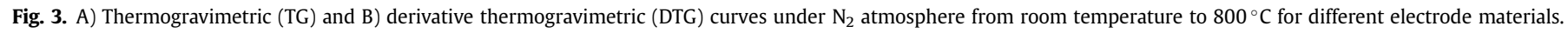

Keynol and C-Tex exhibited a similar TG and DTG curves with a characteristic region of weight loss (about $25 \%$ ) up to $100^{\circ} \mathrm{C}$. This level of weight loss is attributed to the evaporation of water, as expected due to the hydrophilic behaviour displayed by these electrodes. DTG curve of PAN shows a small weight loss occurring between 300 and $400^{\circ} \mathrm{C}$ mainly caused by the cyclization reaction. During the cyclization, nitrile group form the conjugate $\mathrm{C}=\mathrm{N}$ group leading to the formation of an aromatic ring [32]. According to the results obtained all the electrode materials tested demonstrated thermal stability under inert atmosphere.

\subsubsection{Electrochemical characterization}

Electrochemical measurements (abiotic) were performed in a $250 \mathrm{~mL}$ glass electrochemical cell using a potentiostat. Using a three-electrode setup, the reference electrode was $\mathrm{Ag} / \mathrm{AgCl}$ and the counter electrode was a platinum foil. Cyclic voltammograms of Keynol, C-Tex and PAN, performed at different scan rates, are presented in Fig. 4A, C and E, respectively. Keynol and C-Tex curves show a quasi-rectangular shape indicating a strong capacitive behaviour [33]. The capacitive profile is mainly a consequence of the large surface area of the electrodes [34]. At higher scan rates $\left(>10 \mathrm{mV} \mathrm{s}^{-1}\right)$ the shape of the CV curve of Keynol change from quasi-rectangular to elliptical. The change of the curve shape could be due to the lower electrical conductivity and the slower diffusion rate inside the available pores [33]. For PAN, the area limited by the curve is very small compared with the other electrodes, showing its low electrochemical activity (Fig. 4E). By comparison, Keynol exhibited higher catalytic activity than C-Tex and PAN electrodes.

The galvanostatic charge-discharge curves of Keynol, C-Tex and PAN recorded at various current densities $(0.75,1.25,1.90,2.50$ and $5 \mathrm{~mA} \mathrm{~cm}^{-2}$ ) are shown in Fig. 4B, D and F, respectively. The shape of all charge-discharge curves is almost triangular, which suggest a capacitive behaviour of the electrodes [35].

The specific capacitance of the various electrodes was determined from the charge-discharge curves during the discharge process. The capacitance was determined at current density of $2.5 \mathrm{~mA} \mathrm{~cm}^{-2}$. The specific capacitance of Keynol, C-Tex and PAN was $2885 \mathrm{mF} \mathrm{cm}^{-2}, 615 \mathrm{mF} \mathrm{cm}^{-2}$ and $38 \mathrm{mF} \mathrm{cm}^{-2}$, respectively. As expected, Keynol demonstrated the highest capacitance mainly because of the highest $S_{\mathrm{BET}}$.

\subsection{Effect of different anodes on the performance of a MEC under cell potential control versus anode potential control}

\subsubsection{Current generation}

Urine-fed MECs were operated in batch mode under cell potential control to study the effect of three different anodes on the anode performance. Over a period of 38 days, the applied cell potential was step wise $(100 \mathrm{mV})$ increased from $0.4 \mathrm{~V}$ to $0.9 \mathrm{~V}$ (Fig. 5A). During this process, anode potential of the MEC using CTex went up from $-0.418 \mathrm{~V}$ to $-0.200 \mathrm{~V}$ while cathode potential went down from $-0.939 \mathrm{~V}$ to $-1.136 \mathrm{~V}$. The potential difference between anode and cathode increased with applied voltage, and simultaneously the current density increased. However, when the applied cell potential was increased to $0.900 \mathrm{~V}$, anode potential increased (to $-0.200 \mathrm{~V}$ ) and current density decreased, suggesting that the biofilm was negatively affected. For this reason, applied cell voltage was decreased again to $0.800 \mathrm{~V}$. Fig. $5 \mathrm{~A}$ shows that for MEC using C-Tex, setting the applied cell potential at $0.800 \mathrm{~V}$, a current density of $229 \mathrm{~mA} \mathrm{~m}^{-2}$ was produced. Wang and co-workers also demonstrated the increase of current density with the increase of cell potential using carbon cloth as anode [36].

On the other hand, the increase of applied cell potential in the MECs using Keynol and PAN does not seem to have affected the current density generated (Fig. 5A). Hence, the applied cell potential of the MECs using Keynol and PAN was decreased and maintained at $0.400 \mathrm{~V}$. At this applied cell potential, MEC using Keynol produced an average current density of $109 \mathrm{~mA} \mathrm{~m}^{-2}$, whereas the MEC using PAN produced $60 \mathrm{~mA} \mathrm{~m}^{-2}$. Fig. 5B shows the development of current density of MECs operated in continuous mode under anode potential control setting at $-0.300 \mathrm{~V}$. This potential was chosen according to the 1st assay, where the highest current density was obtained at a cell potential of $0.800 \mathrm{~V}$, corresponding to an anode potential of $-0.288 \mathrm{~V}$. The MEC using C-Tex developed current density more quickly and to higher values than MECs using the other anodes. With the anode potential set at $-0.300 \mathrm{~V}$, an average current density of $904 \mathrm{~mA} \mathrm{~m}^{-2}$ was obtained using C-Tex, a value around 4-fold higher than that obtained with the applied cell potential at $0.800 \mathrm{~V}\left(229 \mathrm{~mA} \mathrm{~m}^{-2}\right)$. Similar tendency was observed for Keynol and PAN. An average current density of $338 \mathrm{~mA} \mathrm{~m}^{-2}$ and $118 \mathrm{~mA} \mathrm{~m}^{-2}$ was achieved for Keynol and PAN, respectively, that is around 3-fold (109 $\mathrm{mA} \mathrm{m-2)}$ and 2-fold $\left(60 \mathrm{~mA} \mathrm{~m}^{-2}\right)$ higher than the current density obtained under cell potential control $(0.400 \mathrm{~V})$. Nam and co-workers demonstrated that maximum volumetric current density production in a MEC was 2.7 times higher when the anode potential was set $(-0.2 \mathrm{~V}$ vs. $\mathrm{Ag} / \mathrm{AgCl})$ compared to adding a fixed voltage $(0.6 \mathrm{~V})$ [37].

More positive anode potential was also tested and showed a diminishment of the current density generated. At an anode potential of $-0.200 \mathrm{~V}$, current densities of $369 \mathrm{~mA} \mathrm{~m}^{-2}$ and $258 \mathrm{~mA}$ $\mathrm{m}^{-2}$ were achieved from the MECs using C-Tex and Keynol, respectively (data not shown). Torres and co-workers also observed that increasing the anode potential $(-0.150 \mathrm{~V}$ vs. SHE to $+0.370 \mathrm{~V}$ vs. SHE) decreased the current density [38]. For the MEC using PAN, 
A

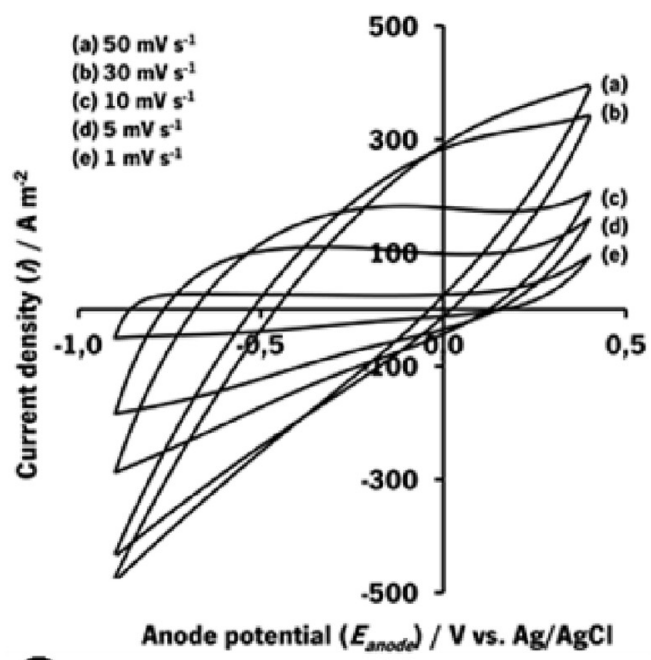

C

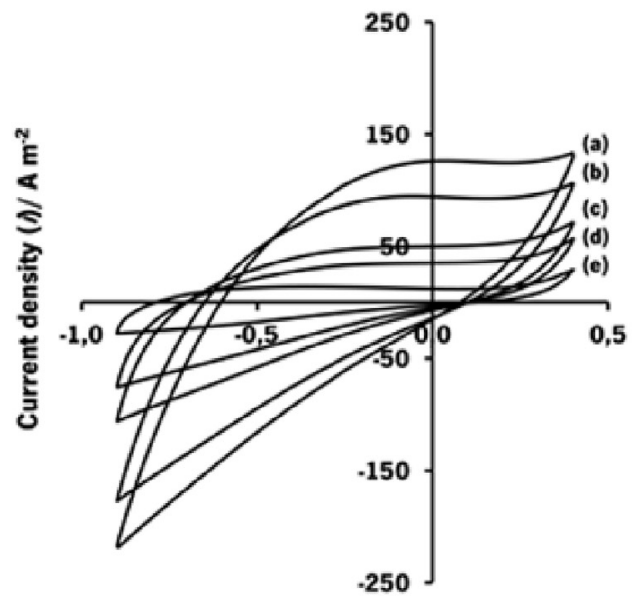

Anode potential $\left(\boldsymbol{E}_{\text {smoded }}\right) / \mathrm{V}$ vs. $\mathrm{Ag} / \mathrm{AgCl}$

E

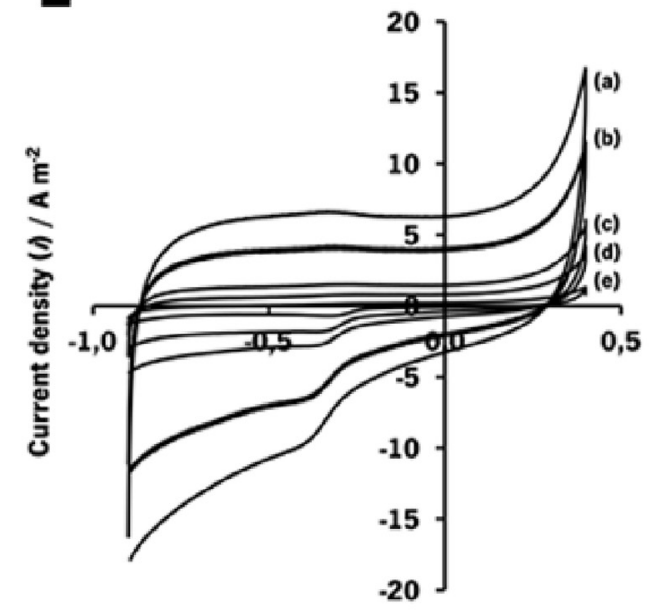

Anode potential $\left(\boldsymbol{E}_{\text {anoded }}\right) / \mathrm{V}$ vs. Ag/AgCl
B

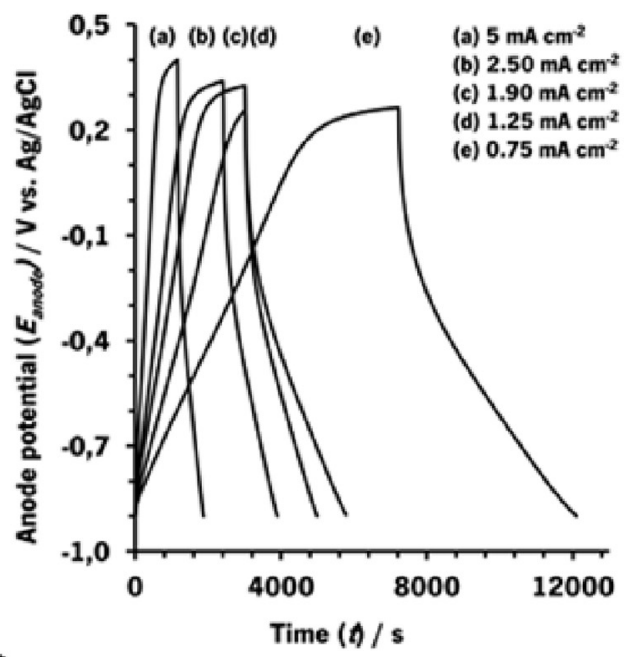

D

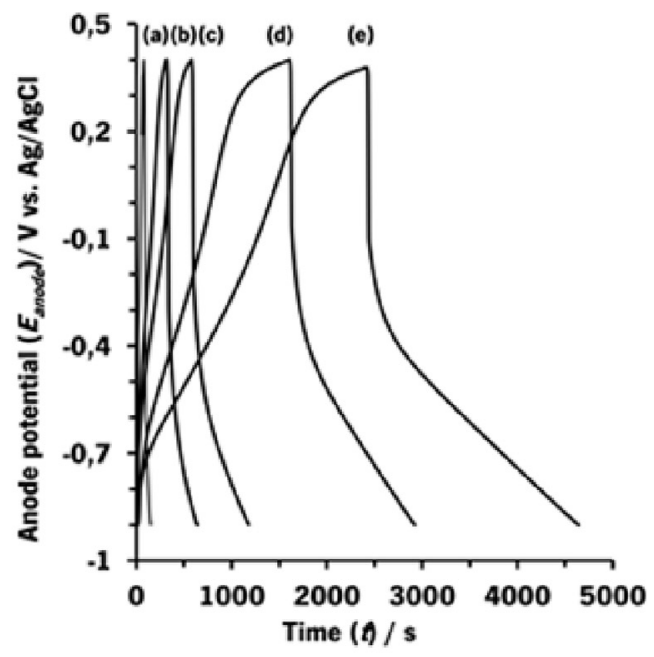

$\mathbf{F}$

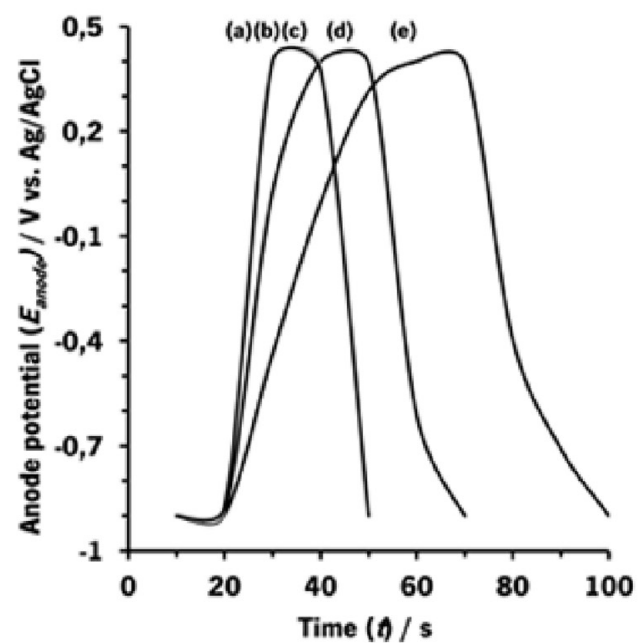

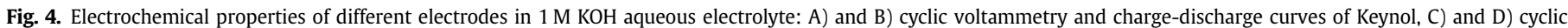
voltammetry and charge-discharge curves of C-Tex and E) and F) cyclic voltammetry and charge-discharge curves of PAN. 

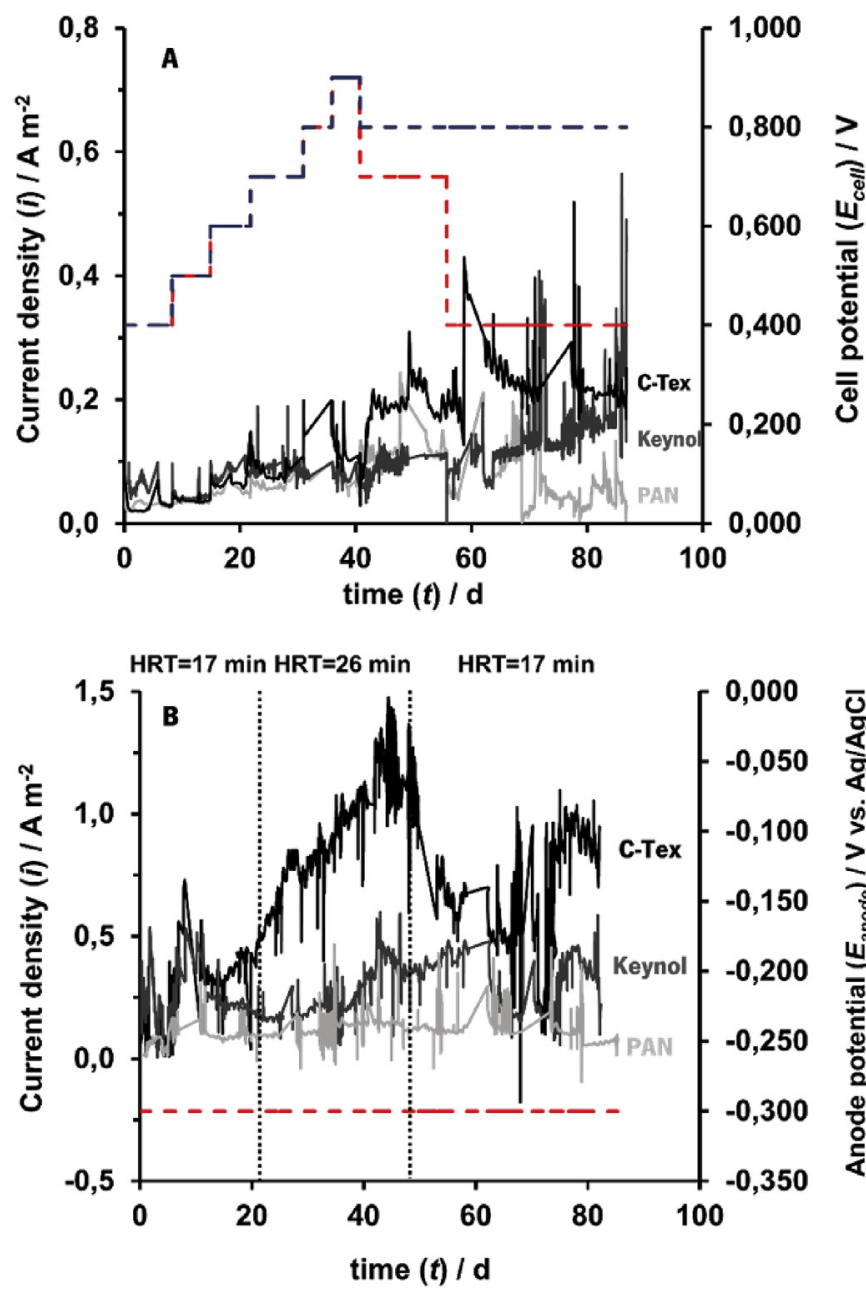

Fig. 5. Measured current density for different anodes (C-Tex, Keynol and PAN) under A) cell potential control in batch mode operation (-- represents the cell potential for C-Tex and -- represents the cell potential for PAN and Keynol) and B) anode potential control in continuous mode operation (-- represents the anode potential).

increasing the anode potential to $-0.200 \mathrm{~V}$ did not influence the generated current $\left(115 \mathrm{~mA} \mathrm{~m}^{-2}\right)$.

By comparison, the results showed that both, under cell and anode potential control, the current density production was higher using C-Tex compared to the other anode materials. The highest current densities obtained in our experiments were $904 \mathrm{~mA} \mathrm{~m}^{-2}$ on C-Tex, $338 \mathrm{~mA} \mathrm{~m}^{-2}$ on Keynol and $118 \mathrm{~mA} \mathrm{~m}^{-2}$ on PAN. The $S_{\text {ext }}$ values of the anodes vary in a similar way as the current densities (C-Tex $305 \mathrm{~m}^{2} \mathrm{~g}^{-1}$, Keynol $70 \mathrm{~m}^{2} \mathrm{~g}^{-1}$ and PAN $13 \mathrm{~m}^{2} \mathrm{~g}^{-1}$ ). This indicates that there is a positive relationship between the current density and the $S_{\text {ext }}$. Since high Sext facilitates the microbial attachment and biofilm formation, this suggest that C-Tex has a higher surface area available for biofilm attachment.

\subsubsection{MEC treatment efficiency}

Higher current densities were obtained at optimum anode potential control $(-0.300 \mathrm{~V})$ (Fig. 5B). Under this operation mode, soluble chemical oxygen demand (sCOD) removal was similar for all anodes studied, ranged from $39 \%$ to $42 \%$ at a HRT of 17 min and from $41 \%$ to $46 \%$ at a HRT of $26 \mathrm{~min}$. These results suggest that the anodes tested did not influence the biodegradability of the urine since the COD removal is similar in all MECs; however, they appear to influence the current density generated. Since the COD removal was similar for all anode materials, the difference in the current density obtained was possibly due to the higher efficiency of chemical energy conversion to electrical energy on C-Tex. The CE was determined for both HRTs when a stable current density was achieved. CE results seemed to be dependent of the anode material used. For both HRTs tested, MEC using C-Tex demonstrated higher CE compared with MECs using Keynol and PAN. At a HRT of $17 \mathrm{~min}$, a CE of $12 \%$ was determined in the MEC with C-Tex, while a CE of $4 \%$ and $2 \%$ was obtained in MECs with Keynol and PAN, respectively. At a HRT of 26 min, a CE of $20 \%$ was obtained in the MEC with C-Tex, whereas a CE of $6 \%$ and $4 \%$ were obtained for MECs with Keynol and PAN, respectively. Fermentation and electricity generation are competitive processes for fermentable substrates in MECs, which can explain the low CEs obtained [39]. Furthermore, the electrons released from the substrate oxidation can be used for gas production $\left(\mathrm{H}_{2}\right.$ or $\left.\mathrm{CH}_{4}\right)$ or lost to alternative electron acceptors (e.g. sulphur or nitrogen compounds), resulting in a lower CE [2]. The CEs obtained in this work are in same range of CE reported in previous studies using wastewater containing fermentable substrates such as food processing wastewater [40] and pig slurry [41].

\subsubsection{Electrochemical characterization}

The voltammograms of each anode were performed at $0.15 \mathrm{mV} \mathrm{s}^{-1}$ between $-0.900 \mathrm{~V}$ and $0.800 \mathrm{~V}$ (Fig. 6). Sigmoidal shaped voltammograms were observed for all anodes suggesting that the current was produced by direct electron transfer from the biofilm [42]. Torres and co-workers demonstrated that the electroactive microorganisms that grown at low anode potentials ($0.150 \mathrm{~V}$ vs SHE) carried out extracellular electron transfer exclusively by conducting electrons through the biofilm [38].

Furthermore, the voltammograms of the different anode materials demonstrate the same shape varying only in the magnitude of the current production. Therefore, the difference in current density obtained can be explained by the difference in the surface area available for microbial growth [42].

\subsubsection{Microbial community analysis}

SEM inspection of the biofilm developed on the different anodes showed that the surfaces were covered with a dense biofilm composed of microorganisms with different morphologies and sizes (Fig. 7). Rods and cocci shape microorganisms were observed in all biofilms. SEM images show that microorganisms not just

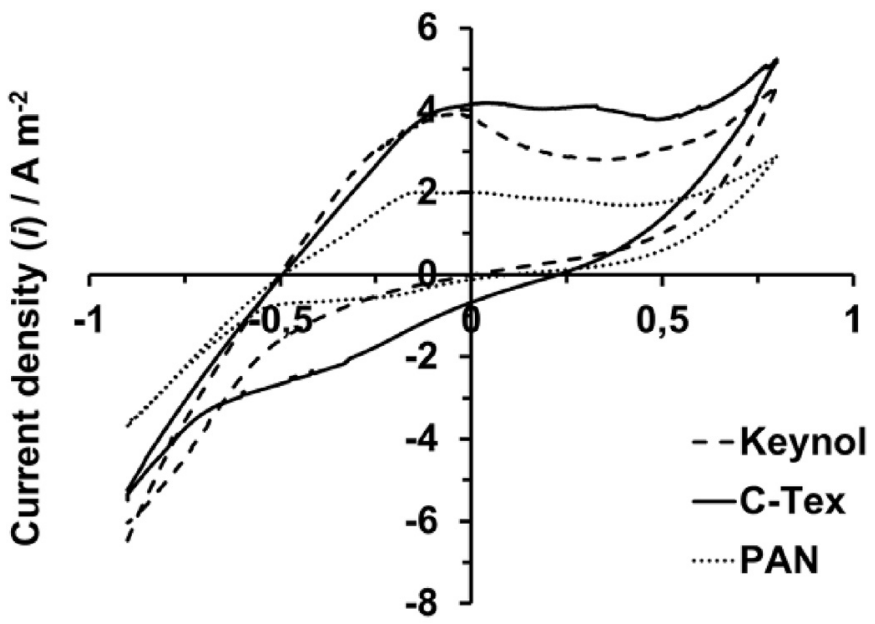

Anode potential $\left(E_{\text {anode }}\right) / \mathrm{V}$ vs. $\mathrm{Ag} / \mathrm{AgCl}$

Fig. 6. Cyclic voltammograms of biofilms developed in the different anodes. The scanning rate was $0.15 \mathrm{mV} \mathrm{s}^{-1}$ and $\mathrm{Ag} / \mathrm{AgCl}$ was used as the reference electrode. 

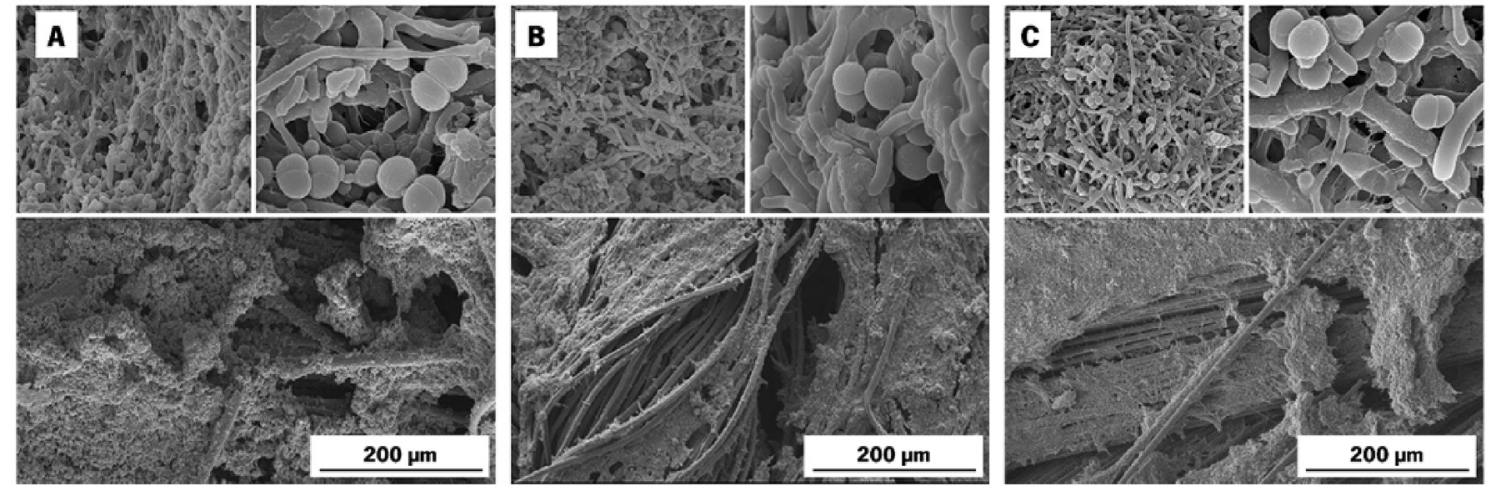

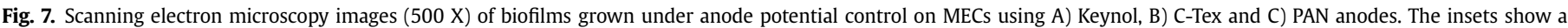
higher magnification image of the biofilm (left: 10 000x, and right: 50 000x).

colonize the carbon fibers but also form a multilayer and compact biofilm structure. As a consequence, most cells were not in direct contact with the anode. Furthermore, some mineral deposits were also observed when Keynol was used. EDS analysis revealed that the crystals observed on the Keynol surface were mainly composed by $\mathrm{Ca}(67 \%), \mathrm{O}(21 \%)$ and $\mathrm{C}(11 \%)$. Tilley and co-workers reported the precipitation of calcite $\left(\mathrm{CaCO}_{3}\right)$, among other crystals, in collection and storage systems of urine due to the increase of $\mathrm{pH}$ as a consequence of urea hydrolysis [43].

The microbial community composition of the biofilm developed in both assays, under cell and anode potential control, in each electrode material was analysed by 16S rDNA high throughout sequencing and compared with the anaerobic inoculum (Fig. 8).

Fig. 8A shows that microorganisms identified in the urine adapted sludge used to inoculate all MECs could be assigned into four groups. Firmicutes was the dominant bacterial phylum representing $27 \%$ of the total analysed population, whereas Proteobacteria was the second most abundant phylum identified representing $18 \%$ of the total population followed by Actinobacteria and Bacteroidetes phyla with $12 \%$ and $7 \%$, respectively. By comparison with initial inoculum it is possible to observe that a process of enrichment and selection occurred during the operation in the MECs using different anode materials both under cell potential control and anode potential control.

Under cell potential control, Firmicutes and Proteobacteria accounted for more than $80 \%$ of the total population in MECs using C-Tex and PAN and 65\% of the total population in MEC using Keynol Assigned to the Firmicutes phylum, the anodic biofilm was dominated by Lactobacillales and Tissierellales orders. Lactobacillales specifically occurred in the anode biofilm of the MEC using C-Tex (70\%), while in the MECs using Keynol and PAN Lactobacillales are in similar percentage (35\% and $28 \%$, respectively) with Tissierellales (33\% and 35\%, respectively). Atopostipes sp representing 17\%-34\% of the Lactobacillales order is known as fermentative bacteria, which can use carbohydrates such as glucose to lactate, acetate, and formate [44]. The remaining percentage of Lactobacillales was classified as "unknown". Trichococcus bacteria, an example of a bacteria assigned to the Lactobacillales order was reported by Takahashi and co-workers due to its capability of utilizing electrodes as extracellular electron acceptors producing electricity from rice bran [45]. Tissierella creatinhophila representing 41\%-53\% of the Tissierellales order, has the ability to grow on urine, metabolizing creatinine as sole carbon source to acetate, methylamine, ammonia and carbon dioxide [46]. Betaproteobacteria and Gammaproteobacteria classes, assigned to the Proteobacteria phylum, were the most abundant in biofilm developed in all electrodes. Burkholderiales belonging to Betaproteobacteria class largely dominated the anodic biofilm representing $75 \%$ of the sample taken from the MEC using Keynol; 83\% using C-Tex and 90\% using PAN, (Fig. 8B). Oligella ureolytica was identified in the biofilms developed on MECs using C-Tex and PAN representing more than $70 \%$ of the total population assigned to Burkholderiales order and more than $20 \%$ of the total sequences analysed, while the biofilm developed in MEC using Keynol these bacteria represents only 10\%. Oligella ureolytica has been described as a non-fermentative bacteria capable to reduce nitrate to nitrite [47]. Oligella also has been reported to as urease-positive, which means that it has the capability to hydrolyse urea [48]. Pseudomonadales and Enterobacteriales are the most abundant orders belonging to the Gammaproteobacteria class. Most bacterial species affiliated with class Gammaproteobacteria are considered electrochemically active bacteria. Several authors have reported the ability of Pseudomonas sp to produce electricity by producing electron shuttles to enhance electron-transfer rate [49] as well as the capability of Enterobacter sp of using a wide range of substrates such as cellulose, sucrose and glycerol to generate electricity [50].

Under anode potential control, a clear selection in the community composition was observed when comparing the original anaerobic inoculum with the anode biofilms. These results show that Firmicutes phyla was largely enriched in the anodic communities accounting from $79 \%$ to $88 \%$ of the total population (Fig. $8 \mathrm{~A}$ ). Lactobacillales was the dominant order assigned to the Firmicutes phylum, specifically in the biofilm developed on C-Tex (68\% of the total Firmicutes population and $54 \%$ of the total sequences analysed)(Fig. 8B). Similarly to the results obtained under cell potential control, Atopostipes sp represent $9 \%-14 \%$ of the total Lactobacillales identified, being the remaining percentage of the Lactobacillales order classified as "unknown". The high percentage of bacteria assigned to Lactobacillales order observed in C-Tex MEC may be related with high current generation since several species belonging to the Lactobacillales order have been described as electrochemically active bacteria (e.g. Trichococcus) [45]. Bacteroidetes was the second most abundant phyla identified in the anodic biofilms representing $5 \%-12 \%$ of the total bacteria population (Fig. 8A). For all anodes studied, more than $90 \%$ of the total Bacteroidetes community was composed by Petrimonas sp which can ferment carbohydrates such as glucose to acetate, $\mathrm{H}_{2}$ and $\mathrm{CO}_{2}$ using nitrate as electron acceptor [51]. Even though the Proteobacteria phylum only represents $1 \%$ of the total population identified in all anodic biofilms, Enterobacteriales order represents around $70 \%$ of the total Proteobacteria population in the biofilm developed on C-Tex. On the other hand, the biofilm developed on CTex under cell potential control showed that Enterobacteriales order represents only $6 \%$ of the Proteobacteria population. 

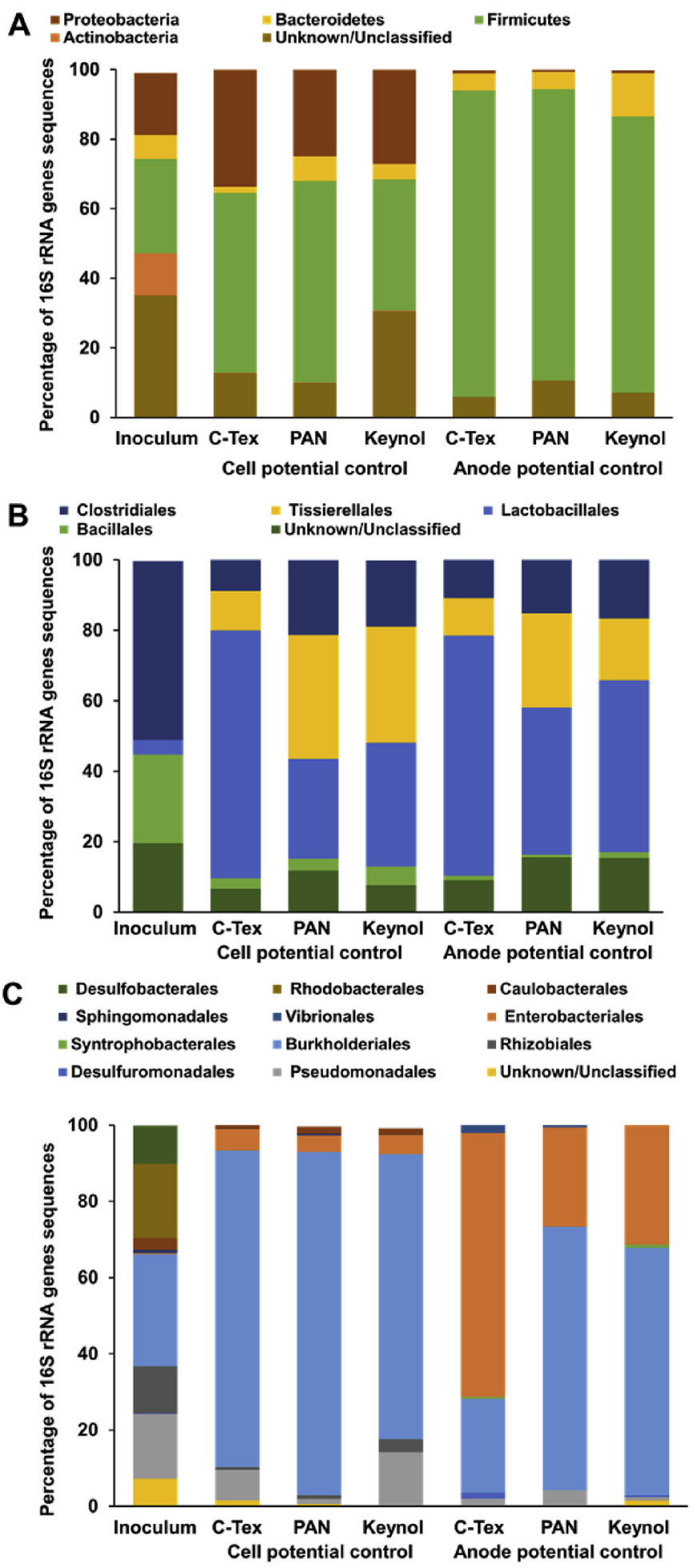

Fig. 8. Bacterial community distribution of biofilm grown on different anodes tested (C-Tex, Pan and Keynol) under cell and anode potential control at A) phylum level, B) order lever assigned to Firmicutes phyla and C) order level assigned to Proteobacteria phyla.

Enterobacter sp. representing $73 \%$ of the Enterobacteriales order may have important influence on current production, since several species belonging to the Enterobacteriales order have been described as electrochemically active bacteria [50,52-54]. Several authors have reported current generation by species belonging to the Enterobacteriales such as Enterobacter cloacae in a mediatorless microbial fuel cell [55]. Furthermore, Geobacter sp assigned to the Desulfuromonadales order was identified in the biofilm developed on the C-Tex under anode potential control. Geobacter have been designated as electrogenic bacteria that have the ability to transfer electrons for an insoluble electron acceptor [56,57].

By comparison of the obtained results, it can be concluded that the different anode materials studied have no effects on the microbial diversity developed. Fig. 8 demonstrates there are no visible differences in the diversity of bacteria identified in the different biofilms obtained whether under cell or anode potential control. However, the different anodes appear to promote the growth of some microorganisms to the detriment of others. In general, compared with biofilms developed on Keynol and PAN, the biofilm developed on C-Tex presented a higher percentage of microorganisms assigned to Lactobacillales order. Furthermore, the biofilm developed on C-Tex with controlled anode potential presented a higher percentage of microorganisms assigned to Enterobacteriales order. The biofilm developed under this condition also generated a higher current density.

\section{Conclusions}

This study demonstrated that urine fed MEC with C-Tex as anode produced higher current density than MECs using Keynol or PAN. After accounting for differences in the anodes textural, chemical and electrochemical characteristics, the results suggest that the higher external surface area of the C-Tex, which corresponds to the surface area excluding the micropores contribution, enabled the higher current density generation compared to Keynol and PAN. Different anode materials had no differences on microbial diversity. Firmicutes and Proteobacteria were the dominant phyla in the all anode materials. Lactobacillales assigned to Firmicutes phyla and Enterobacteriales assigned to Proteobacteria phyla where the dominant orders identified in the biofilm developed on C-Tex, suggesting that bacteria assigned to these orders may be correlated with the higher current generation.

\section{Acknowledgements}

This study was supported by the European Union's Seventh Programme for research, technological development and demonstration [Grant number 308535] and by the Portuguese Foundation for Science and Technology (FCT) under the scope of the strategic funding of UID/BIO/04469/2013 unit and COMPETE 2020 [POCI-010145-FEDER-006684], of Project RECI/BBB-EBI/0179/2012 [FCOMP01-0124-FEDER-027462], POCI-01-0145-FEDER-007679 [UID/CTM/ 50011/2013], and by BioTecNorte operation [NORTE-01-0145FEDER-000004] funded by the European Regional Development Fund under the scope of Norte2020 - Programa Operacional Regional do Norte. This work is a result of project "AIProcMat@N2020 - Advanced Industrial Processes and Materials for a Sustainable Northern Region of Portugal 2020", with the reference NORTE-01-0145-FEDER-000006, supported by Norte Portugal Regional Operational Programme (NORTE 2020), under the Portugal 2020 Partnership Agreement, through the European Regional Development Fund (ERDF) and of Project POCI-01-0145FEDER-006984 - Associate Laboratory LSRE-LCM funded by ERDF through COMPETE2020 - Programa Operacional Competitividade e Internacionalização (POCI) - and by national funds through FCT. The authors also would like to acknowledge the support of Wetsus, European Centre of Excellence for Sustainable Water Technology. 


\section{Appendix A. Supplementary data}

Supplementary data related to this article can be found at https://doi.org/10.1016/j.electacta.2018.02.083.

\section{References}

[1] B.E. Logan, D. Call, S. Cheng, H.V.M. Hamelers, T.H.J.A. Sleutels A.W. Jeremiasse, R.A. Rozendal, Microbial electrolysis cells for high yield hydrogen gas production from organic matter, Environ. Sci. Technol. 42 (2008) 8630-8640.

[2] J. Ditzig, H. Liu, B.E. Logan, Production of hydrogen from domestic wastewater using a bioelectrochemically assisted microbial reactor (BEAMR), Int. J. Hydrogen Energy 32 (2007) 2296-2304.

[3] A. Escapa, L. Gil-Carrera, V. García, A. Morán, Performance of a continuous flow microbial electrolysis cell (MEC) fed with domestic wastewater, Bioresour Technol. 117 (2012) 55-62.

[4] E.S. Heidrich, J. Dolfing, K. Scott, S.R. Edwards, C. Jones, T.P. Curtis, Production of hydrogen from domestic wastewater in a pilot-scale microbial electrolysis cell, Appl. Microbiol. Biotechnol. 97 (2013) 6979-6989.

[5] P. Ledezma, P. Kuntke, C.J.N. Buisman, J. Keller, S. Freguia, Source-separated urine opens golden opportunities for microbial electrochemical technologies, Trends Biotechnol. 33 (2015) 214-220.

[6] T.A. Larsen, W. Gujer, Separate management of anthropogenic nutrient solutions (human urine), in: Water Sci. Technol, 1996, pp. 87-94.

[7] P. Kuntke, T.H.J.A. Sleutels, M. Saakes, C.J.N. Buisman, Hydrogen production and ammonium recovery from urine by a microbial electrolysis cell, Int. J. Hydrogen Energy 39 (2014) 4771-4778.

[8] K. Artyushkova, J.A. Cornejo, L.K. Ista, S. Babanova, C. Santoro, P. Atanassov, A.J. Schuler, Relationship between surface chemistry, biofilm structure, and electron transfer in Shewanella anodes, Biointerphases 10 (2015) 1-12.

[9] D. Call, B.E. Logan, Hydrogen production in a single chamber microbial electrolysis cell lacking a membrane, Environ. Sci. Technol. 42 (2008) 3401-3406.

[10] H. Liu, S. Grot, B.E. Logan, Electrochemically assisted microbial production of hydrogen from acetate, Environ. Sci. Technol. 39 (2005) 4317-4320.

[11] S. Cheng, B.E. Logan, Sustainable and efficient biohydrogen production via electrohydrogenesis, Proc. Natl. Acad. Sci. U. S. A 104 (2007) 18871-18873.

[12] S.E. Oh, B.E. Logan, Proton exchange membrane and electrode surface areas as factors that affect power generation in microbial fuel cells, Appl. Microbiol. Biotechnol. 70 (2006) 162-169.

[13] P.A. Selembo, M.D. Merrill, B.E. Logan, The use of stainless steel and nickel alloys as low-cost cathodes in microbial electrolysis cells, J. Power Sources 190 (2009) 271-278.

[14] Y. Fan, S. Xu, R. Schaller, J. Jiao, F. Chaplen, H. Liu, Nanoparticle decorated anodes for enhanced current generation in microbial electrochemical cells, Biosens. Bioelectron. 26 (2011) 1908-1912.

[15] K. Guo, S. Freguia, P.G. Dennis, X. Chen, B.C. Donose, J. Keller, J.J. Gooding, K. Rabaey, Effects of surface charge and hydrophobicity on anodic biofilm formation, community composition, and current generation in bioelectrochemical systems, Environ. Sci. Technol. 47 (2013) 7563-7570.

[16] S.G. Barbosa, L. Peixoto, B. Meulman, M.M. Alves, M.A. Pereira, A design of experiments to assess phosphorous removal and crystal properties in struvite precipitation of source separated urine using different Mg sources, Chem. Eng. J. 298 (2016) 146-153.

[17] F. Rodriguez-Reinoso, J.M. Martin-Martinez, C. Prado-Burguete, B. Mcenaney A Standard adsorption isotherm for the characterization of activated carbons, J. Phys. Chem. 91 (1987) 515-516.

[18] B. Li, J. Zhou, X. Zhou, X. Wang, B. Li, C. Santoro, M. Grattieri, S. Babanova, K. Artyushkova, P. Atanassov, A.J. Schuler, Surface modification of microbial fuel cells anodes: approaches to practical design, Electrochim. Acta 134 (2014) $116-126$.

[19] L. Zu, X. Cui, Y. Jiang, Z. Hu, H. Lian, Y. Liu, Y. Jin, Y. Li, X. Wang, Preparation and electrochemical characterization of mesoporous polyaniline-silica nanocomposites as an electrode material for pseudocapacitors, Materials (Basel) 8 (2015) 1369-1383.

[20] J.G. Caporaso, C.L. Lauber, W.A. Walters, D. Berg-Lyons, C.A. Lozupone, P.J. Turnbaugh, N. Fierer, R. Knight, Global patterns of $16 \mathrm{~S}$ rRNA diversity at depth of millions of sequences per sample, Proc. Natl. Acad. Sci. 108 (2011) 4516-4522.

[21] D. Pr Herlemann, M. Labrenz, K. Jürgens, S. Bertilsson, J.J. Waniek, A.F. Andersson, Transitions in bacterial communities along the $2000 \mathrm{~km}$ salinity gradient of the Baltic Sea, ISME J. 541 (2011) 1571-1579.

[22] K. Takai, K. Horikoshi, Rapid detection and quantification of members of the archaeal community by quantitative PCR using fluorogenic probes, Appl. Environ. Microbiol. 66 (2000) 5066-5072.

[23] J. Figueiredo, M.F. Pereira, M.M. Freitas, J.J. Órfão, Modification of the surface chemistry of activated carbons, Carbon N. Y. 37 (1999) 1379-1389.

[24] R. Rocha, O. Soares, J. Figueiredo, M. Pereira, Tuning CNT properties for metalfree environmental catalytic applications, C 2 (2016) 2-18.

[25] X. Chen, D. Cui, X. Wang, X. Wang, W. Li, Porous carbon with defined pore size as anode of microbial fuel cell, Biosens. Bioelectron. 69 (2015) 135-141.

[26] J.A. Menéndez-Diaz, I. Martín-Gullón, Types of carbon adsorbents and their production, in: T.J. Bandosz (Ed.), Act. Carbon Surfaces Environ. Remediat.
First, Elsevier, New York, 2006, pp. 1-45

[27] M. Thommes, K. Kaneko, A.V. Neimark, J.P. Olivier, F. Rodriguez-Reinoso, J. Rouquerol, K.S.W. Sing, Physisorption of gases, with special reference to the evaluation of surface area and pore size distribution (IUPAC Technical Report), Pure Appl. Chem. 87 (2015) 1051-1069.

[28] Y. Liu, F. Harnisch, K. Fricke, U. Schröder, V. Climent, J.M. Feliu, The study of electrochemically active microbial biofilms on different carbon-based anode materials in microbial fuel cells, Biosens. Bioelectron. 25 (2010) 2167-2171.

[29] M. Lu, Y. Qian, L. Huang, X. Xie, W. Huang, Improving the performance of microbial fuel cells through anode manipulation, Chempluschem 80 (2015) 1216-1225.

[30] S. Ishii, S. Suzuki, T.M. Norden-Krichmar, T. Phan, G. Wanger, K.H. Nealson, Y. Sekiguchi, Y.A. Gorby, O. Bretschger, Microbial population and functional dynamics associated with surface potential and carbon metabolism, ISME J. 8 (2014) 963-978.

[31] A. Ribeiro, V. Volkov, M.B. Oliveira, J. Padrão, J.F. Mano, A.C. Gomes, A. CavacoPaulo, BSA/HSA ratio modulates the properties of $\mathrm{Ca}^{2+}$-induced cold gelation scaffolds, Int. J. Biol. Macromol. 89 (2016) 535-544.

[32] I.M. Alarifi, A. Alharbi, W.S. Khan, A. Swindle, R. Asmatulu, Thermal, electrical and surface hydrophobic properties of electrospun polyacrylonitrile nanofibers for structural health monitoring, Materials (Basel) 8 (2015) 7017-7031.

[33] M. Minakshi Sundaram, A. Biswal, D. Mitchell, R. Jones, C. Fernandez, Correlation among physical and electrochemical behaviour of nanostructured electrolytic manganese dioxide from leach liquor and synthetic for aqueous asymmetric capacitor, Phys. Chem. Chem. Phys. 18 (2016) 4711-4720.

[34] M. Natalia, Y.N. Sudhakar, M. Selvakumar, Activated carbon derived from natural sources and electrochemical capacitance of double layer capacitor, Indian J. Chem. Technol. 20 (2013) 392-399.

[35] C.K. Sim, S.R. Majid, N.Z. Mahmood, Electrochemical performance of activated carbon derived from treated food-waste, Int. J. Electrochem. Sci. 10 (2015) 10157-10172.

[36] A. Wang, W. Liu, N. Ren, J. Zhou, S. Cheng, Key factors affecting microbial anode potential in a microbial electrolysis cell for $\mathrm{H}_{2}$ production, Int. J. Hydrogen Energy 35 (2010) 13481-13487.

[37] J. Nam, J.C. Tokach, B.E. Logan, Comparison of microbial electrolysis cells operated with added voltage or by setting the anode potential, Int. J. Hydrogen Energy 36 (2011) 10550-10556.

[38] C.I. Torres, R. Krajmalnik-Brown, P. Parameswaran, A.K. Marcus, G. Wanger, Y.A. Gorby, B.E. Rittmann, Selecting anode-respiring bacteria based on anode potential: phylogenetic, electrochemical, and microscopic characterization, Environ. Sci. Technol. 43 (2009) 9519-9524.

[39] D. Pant, G. Van Bogaert, L. Diels, K. Vanbroekhoven, A review of the substrates used in microbial fuel cells (MFCs) for sustainable energy production, Bioresour. Technol. 101 (2010) 1533-1543.

[40] A. Tenca, R.D. Cusick, A. Schievano, R. Oberti, B.E. Logan, Evaluation of low cost cathode materials for treatment of industrial and food processing wastewater using microbial electrolysis cells, Int. J. Hydrogen Energy 38 (2013) 1859-1865.

[41] M. Cerrillo, J. Oliveras, M. Viñas, A. Bonmatí, Comparative assessment of raw and digested pig slurry treatment in bioelectrochemical systems, Bioelectrochemistry 110 (2016) 69-78.

[42] D.V.P. Sanchez, D. Jacobs, K. Gregory, J. Huang, Y. Hu, R. Vidic, M. Yun, Changes in carbon electrode morphology affect microbial fuel cell performance with Shewanella oneidensis MR-1, Energies 8 (2015) 1817-1829.

[43] E. Tilley, J. Atwater, D. Mavinic, Recovery of struvite from stored human urine, Environ. Technol. 29 (2008) 797-806.

[44] M.A. Cotta, T.R. Whitehead, M.D. Collins, P.A. Lawson, Atopostipes suicloacale gen. nov., sp. nov., isolated from an underground swine manure storage pit, Anaerobe 10 (2004) 191-195.

[45] S. Takahashi, M. Miyahara, A. Kouzuma, K. Watanabe, K. Rice, Electricity generation from rice bran in microbial fuel cells, Bioresour. Bioprocess 3 (2016) $1-5$.

[46] C. Harrns, A. Schleicher, M.D. Collins, J.R. Andreesen, Tissierella creatinophila sp. nov., a Gram-positive, anaerobic, non-spore-forming, creatinine-fermenting organism, Int. J. Syst. Bacteriol. 48 (1998) 983-993.

[47] T. Demir, N. Celenk, Bloodstream infection with Oligella ureolytica in a newborn infant: a case report and review of the literature, J. Infect. Dev. Ctries 8 (2014) 793-795.

[48] R. Rossau, K. Kersters, E. Falsen, E. Jantzen, P. Segers, A. Union, L. Nehls, J. DE Ley, Oligella, a new genus including Oligella urethralis comb. Nov. (Formerly Moraxella urethralis) and Oligella ureolytica sp. nov. (Formerly CDC group IVe): relationship to Taylorella equigenitalis and related Taxa, Int. J. Syst. Bacteriol. 37 (1987) 198-210.

[49] K. Rabaey, N. Boon, M. Höfte, W. Verstraete, Microbial phenazine production enhances electron transfer in biofuel cells, Environ. Sci. Technol. 39 (2005) 3401-3408.

[50] C. Feng, J. Li, D. Qin, L. Chen, F. Zhao, S. Chen, H. Hu, C.P. Yu, Characterization of exoelectrogenic bacteria Enterobacter strains isolated from a microbial fuel cell exposed to copper shock load, PLoS One 9 (2014) e113379.

[51] A. Grabowski, B.J. Tindall, V. Bardin, D. Blanchet, C. Jeanthon, Petrimonas sulfuriphila gen. nov., sp. nov., a mesophilic fermentative bacterium isolated from a biodegraded oil reservoir, Int. J. Syst. Evol. Microbiol. 55 (2005) $1113-1121$.

[52] S. Tanisho, N. Kamiya, N. Wakao, Microbial fuel cell using Enterobacter aerogenes, Bioelectrochem. Bioenerg. 21 (1989) 25-32. 
[53] F. Rezaei, D. Xing, R. Wagner, J.M. Regan, T.L. Richard, B.E. Logan, Simultaneous cellulose degradation and electricity production by Enterobacter cloacae in a microbial fuel cell, Appl. Environ. Microbiol. 75 (2009) 3673-3678.

[54] V.R. Nimje, C.Y. Chen, C.C. Chen, J.Y. Tsai, H.R. Chen, Y.M. Huang, J.S. Jean, Y.F. Chang, R.C. Shih, Microbial fuel cell of Enterobacter cloacae: effect of anodic $\mathrm{pH}$ microenvironment on current, power density, internal resistance and electrochemical losses, Int. J. Hydrogen Energy 36 (2011) 11093-11101.

[55] R. Toczyłowska-Mami Ska, K. Szymona, H. Madej, W.Z. Wong, A. Bala, W. Brutkowski, K. Krajewski, P. San H 'ng, M. Mami Ski, Cellulolytic and electrogenic activity of Enterobacter cloacae in mediatorless microbial fuel cell Appl. Energy 160 (2015) 88-93.

[56] L. Peixoto, A.L. Rodrigues, G. Martins, A. Nicolau, A.G. Brito, M.M. Silva, P. Parpot, R. Nogueira, A flat microbial fuel cell for decentralized wastewater valorization: process performance and optimization potential, Environ. Technol. 34 (2013) 1947-1956.

[57] N. LaBarge, Y.D. Yilmazel, P.-Y. Hong, B.E. Logan, Effect of pre-acclimation of granular activated carbon on microbial electrolysis cell startup and performance, Bioelectrochemistry 113 (2017) 20-25. 